\title{
Sins of Omission: Transgressive Genders, Subversive Sexualities, and Confessional Silences in John Gower's Confessio Amantis. ${ }^{1}$
}

\section{Diane Watt}

The relationship between confessional discourse, interiority or self-consciousness, and the regulation of sexuality is well established. ${ }^{2}$ Yet, while in orthodox Christian thought the soul itself was held to be sexless, the penitential literature of the Middle Ages was gendered: it was written by and primarily for men. As Jacqueline Murray has explained "confession and penance was in itself a singularly androcentric sacrament ... whenever women enter the discussion it is as a marked category, a signal of difference, exception or emphasis."33 Further, if, as Michel Foucault famously claimed, confession is “one of the West's most highly valued techniques for producing truth," ${ }^{4}$ the medieval church demanded that some truths -- and specifically some sexual truths -- should be produced only partially. As Allen J. Frantzen puts it, "confession was a site of contradictory demands and impulses." 5 Frantzen's comment refers specifically to sins which were considered to be contrary to nature, such as

\footnotetext{
${ }^{1}$ Early versions of this paper were delivered at the International Medieval Congress at the University of Leeds, $17^{\text {th }}$ July 1997 , and the $33^{\text {rd }}$ International Congress on Medieval Studies at Western Michigan University, $7^{\text {th }}$ May 1998. I am grateful to the organizers of the sessions for inviting me to participate.

${ }^{2}$ See Michel Foucault, The History of Sexuality Volume I: An Introduction, trails. Robert Hurley (London: Allen Lane, 1979); and also Jeremy Tambling, Confession: Sexuality, Sin, the Subject (Manchester: Manchester University Press, 1990), esp. 35-65.

3 Jacqueline Murray, "Gendered Souls in Sexed Bodies: The Male Construction of Female Sexuality in Some Medieval Confessors' Manuals" in Handling Sin: Confession in the Middle Ages, ed. Peter Biller and A.J. Minnis (Woodbridge, Suffolk: Boydell and Brewer, 1998), 79-93; 80-1.

${ }^{4}$ Foucault, History, 59.

5 Allen J. Frantzen, “The Disclosure of Sodomy in Cleanness,” PMLA 111 (1996), 451-64; 455.
} 
bestiality, self-abuse (or masturbation), and sodomy; all subjects which, within a confessional context, had to be broached indirectly, if they were to be broached at all. The fourteenth-century Book of Vices and Virtues, for example, demanded that unnatural vice should be confessed, but described it as "so foul pat it is abhomynacioun to speke it."6 Sinful acts specific to sodomites as well as to women (and the two categories were not mutually exclusive in the Middle Ages), ${ }^{7}$ remained unspoken or only partially articulated in the discourse of the medieval confessional.

John Gower's English poem, Confessio Amantis, makes use of a penitential framework within a fictive and secular context. The unsuccessful lover, Amans, confesses his sins to Genius, the servant of Venus, while the priest elaborates his taxonomy of vices through a series of exemplary narratives. ${ }^{8}$ As might be expected, this text is revealing about medieval notions of masculine heterosexuality, although at the same time its exploration of femininity seems somewhat superficial. It is my argument, however, that Gower is also concerned within this text with the

\footnotetext{
6 W. Nelson Francis, ed., The Book of Vices and Virtues, EETS o.s. 217 (London: OUP, 1942), 46.

7 St Thomas Aquinas defined sodomy as intercourse "with a person of the same sex, male with male and female with female": Temperance (2a2ae), q.154, a.11. All references to Aquinas's discussion of sexuality are to Summa Theologiae, ed. and trans. Thomas Gilby, (London: Blackfriars, 1964-1976), vol.43.

8 On the poem's penitential framework, see John J. McNally, “The Penitential and Courtly Tradition in Gower's Confessio Amantis," Studies in Medieval Culture 1 (1964) 74-94; Mary Flowers Braswell, The Medieval Sinner: Characterization and Confession in the Literature of the English Middle Ages (Rutherford: Fairleigh Dickinson University Press, 1983), 81-87; Gerald Kinneavy, “Gower’s

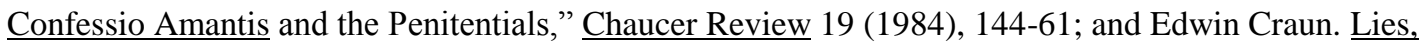
Slander, and Obscenity in Medieval English Literature: Pastoral Rhetoric and the Deviant Speaker (Cambridge: Cambridge University Press, 1997), 113-156, esp. 115-118.
} 
examination of other gendered identities--effeminacy and female masculinity in particular--which we might describe as "transgressive" because they cross over and obfuscate the divide between male and female. Furthermore, with its foregrounding of

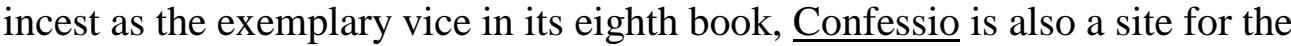
exploration of what might be termed "subversive" sexualities, both male and female (subversive in the sense that they challenge societal norms and expose their inconsistencies). ${ }^{9}$ In the final chapter of her recent book, Covert Operations, Karma Lochrie stresses the importance of examining the intersection of gender ideology and sexual oppression in order to counter-balance what she describes as "the dangerously narrow focus on sexuality in the Middle Ages that either excludes gender from its analysis or worse, posits gender as the conservative constraint that sexuality subverts."10 In her analysis, sexuality (whether normative or otherwise) is actually supported by conservative gender ideology. The current article develops Lochrie's

\footnotetext{
${ }^{9}$ There have been a number of fascinating recent readings of Confessio which focus on the treatment of women and incest, but the studies most relevant to my own approach are Rosemary Woolf, "Moral Chaucer and Kindly Gower" in J.R.R. Tolkien, Scholar and Storyteller: Essays in Memoriam, ed. Mary Salu and Robert T. Farrell (Ithaca: Cornell University Press, 1979), 221-45, and chapter five of Karma Lochrie's Covert Operations: the Medieval Uses of Secrecy (Philadelphia: University of Pennsylvania Press, 1999), 177-227. For reasons which will soon become apparent, I am not using the term "subversive" as a synonym for the term "perverse," as used by Lochrie in the chapter just cited. Nor am I using it as a synonym for the medieval concept of "unnatural" vice because incest was not defined as contrary to nature. That incest should be taken by Genius as representative of the sin of luxuria or lust is all the more surprising when one considers that, according to Thomist thought, in respect to its gravity, incest is only the penultimate subcategory and those sexual sins which Aquinas believed were contrary to nature are even more serious: Temperance (2a2ae), q.154, a.12.

${ }^{10}$ Lochrie, Covert Operations, 226.
} 
thesis in some directions, but in its analysis of Confessio Amantis it comes to rather different conclusions. According to Lochrie's reading of Confessio, Gower "fails to make clear distinctions between natural and unnatural forms of love, much less between heterosexuality and homosexuality." ${ }^{11}$ Lochrie goes on to contend, however, that Gower adheres to a conservative gender ideology even as he reveals its inconsistencies, and she concludes that "for all its perversions, Gower's text is not finally subversive."12 Lochrie's opinion that "John Gower is on the side of order, unity, and social hierarchy" is one with which I do not entirely concur. ${ }^{13}$ Yet, although I argue that Gower does not shy away from discussing some forms of gender trangression and sexual subversion, and although, as will be seen, "unnatural" female

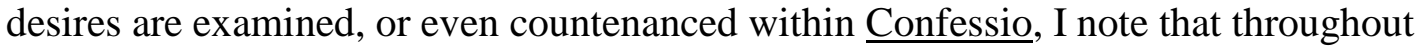
this extremely long text, male sodomy remains taboo. ${ }^{14}$ In this essay, I begin by examining the homosocial and potentially homoerotic relationships between Amans and Cupid and Amans and Genius, before focusing on three exemplary narratives

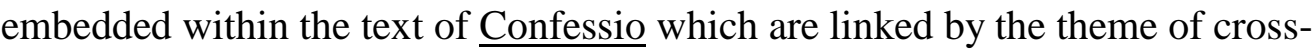
dressing. ${ }^{15}$ In what follows, I suggest that these narratives reveal Gower's concerns about the unstable distinctions between the categories of male and female, masculine and feminine, manliness and effeminacy, ethical and unethical behavior, and natural

\footnotetext{
11 Lochrie, Covert Operations, 221.

12 Lochrie, Covert Operations, 225.

${ }^{13}$ Lochrie, Covert Operations, 226.

14 Lochrie acknowledges the absence of sodomy in Gower's text, but only in passing. She does not explore the significance of this silence.

15 On the cultural significance of cross-dressing, see Marjorie Garber, Vested Interests: Cross-Dressing and Cultural Anxiety (London: Penguin, 1993).
} 
and unnatural love. In the final section, I examine the meaning of Genius's silence on the subject of sodomy between men.

\section{Amans, Cupid, and Genius}

Recent studies of sodomy in the Middle Ages have illustrated that it was widely viewed as a manifestation of feminine (and thus degenerate) and immature impulses, and thus not essentially different from immoderate and uncontrollable heterosexual desire. ${ }^{16}$ From this perspective, Amans' excessive if frustrated longing might be seen to bear some similarity to medieval homosexuality. In addition, at the same time as the object of Amans' desire--the beloved lady--remains absent from Confessio, the frame narrative is dominated by the homosociality, or ho(m)mo-sexuality, ${ }^{17}$ of the relationships between Amans and Cupid, and between Amans and Genius. Only one other figure makes a significant appearance in the frame narrative of $\underline{\text { Confessio: }}$ Venus. Gerald Kinneavy is of the view that, like the priest and the sinner, the goddess of love has a function within the poem's penitential structure. ${ }^{18}$ He points out that proper penance demands cognizance of divine presence; the confessor only serves as an intermediary when the sinner bares his or her soul to the omniscient Creator. Kinneavy argues that in having Venus judge Amans and prescribe his penance at the

\footnotetext{
16 See for example, Elizabeth B. Keiser, Courtly Rhetoric and Medieval Homophobia: The Legitimation of Sexual Pleasure in Cleanness and Its Contexts (New Haven: Yale University Press, 1997), 85. For a fuller analysis, see Lochrie, Covert Operations, 177-227.

17 See Eve Kosofsky Sedgwick, Between Men: English Literature and Male Homosexual Desire (Columbia: Columbia University Press, 1985); and Luce Irigaray, "Women on the Market" in The Sex Which Is Not One, transl. Catherine Porter and Carolyn Burke (Ithaca, NY: Cornell University Press,
} 1985), 170-197.

18 Kinneavy, “Gower's Confessio Amantis," 152. 
end of the poem, "Gower employs a kind of deus (or dea) ex machina." Venus is privy to the truth of Amans' condition to an extent that Genius cannot be, since he relies entirely on what Amans chooses to tell him. Kinneavy fails, however, to acknowledge that Cupid's presence is more problematic.

Cupid's position is ambiguous because he not only relieves Amans' suffering, but also is ultimately responsible for it. Cupid is, then, both tempter and redeemer, and his relationship with Amans is deeply homoerotic. At the start of the poem, Amans falls victim to Cupid's phallic arrow: "Bot he that kyng with yhen wrothe / His chiere aweiward fro me caste, / And forth he passede ate laste. / Bot natheles er he forthe wente / A firy Dart me thoghte he hente / And threw it thurgh myn herte rote" (I.140-5). ${ }^{19}$ Cupid's disdainful demeanor, while entirely conventional, anticipates that of the distant and dismissive lady to whom the lover devotes himself. In his supplication to Venus and Cupid in Book VIII, Amans compares his own powerlessness in the face of love to that of Pan, "which is the god of kinde": (VIII.2240), but who is, of course, also traditionally associated with lechery. ${ }^{20}$ Amans describes his inner conflict as a perpetual wrestling match which he can never win:

For evere I wrastle and evere I am behinde,

That I no strengthe in al min herte finde,

\footnotetext{
19 All references to Confessio Amantis are to The English Works of John Gower, ed. G. C. Macaulay, EETS e.s. 81, 82 (London: Kegan Paul, Trench, Trübner, 1900-1901). Compare Troilus and Criseyde I.206-210, in which Cupid's dart is immediately responsible for Troilus' sudden passion. All Chaucer references are to The Riverside Chaucer, ed. Larry D. Benson (Oxford: Oxford University Press, 1988).

${ }^{20}$ See Patricia Merivale, Pan the Goat-God: His Myth in Modern Times (Cambridge Mass.: Harvard University Press, 1969).
} 
Wherof that I mai stonden eny throwe;

So fer mi wit with love is overthrowe.

(VIII.2241-4)

The significance of this metaphor lies in the way that it points, albeit indirectly, towards the emotional, if not physical, encounters between men which are at the heart of Confessio. Some twenty five lines further on, the lover reiterates that it is Venus's son rather than his lady who is responsible for his pain: "The which hath love under his governance, / And in his hond with many a fyri lance / He woundeth ofte, ther he wol noght hele; / And that somdiel is cause of mi querele" (VIII.2269-72; cf. 228790). Consequently, it is only Cupid who is finally able to release Amans from his passion: "This blinde god which mai noght se, / Hath groped til that he me fond; / And as he pitte forth his hond / Upon my body, wher I lay, / Me thoghte a fyri Lancegay, / Which whilom thurgh myn herte he caste, / He pulleth oute ..." (VIII.2794-2800). While Cupid's healing touch suggests that the old man's infatuation is a debilitating disease, comparable to the king's-evil, the choice of language is noteworthy as "grope" clearly has erotic connotations which may extend in this context to "lancegay" (especially in the context of a gesture of withdrawal). ${ }^{21}$ Indeed Rictor Norton has gone so far as to argue that Cupid, like the more familiar figure of Ganymede, is a coded trope within the homosexual tradition. ${ }^{22}$

\footnotetext{
21 "Gropen" can mean "to feel with the hand or fingers, touch, stroke" and "to touch amorously, play with, fondle" (MED 1a and 1d). For the possible figurative use of the word "launce" to mean "penis" see MED (3e). For a detailed discussion of “gropen”, see Catherine S. Cox, “Grope wel bihynde’: the Subversive Erotics of Chaucer's Summoner,” Exemplaria 7 (1995), 145-177; especially 154-155.

22 Rictor Norton, "Lovely Lad and Shame-Faced Catamite," section 5 of The Homosexual Pastoral Tradition (1974; 1997), published on Norton's website at www.infopt.demon.co.uk.
} 
The relationship between confessor and penitent is less sexualized than that between Cupid and Amans, but more fraught. Genius's fictive narratives are ostensibly used for exploring the lover's inner psyche and for bringing about his cure. Yet, as Genius himself is quite literally the first to admit, his own role is divided between that of servant to Venus and that of priest. Consequently he "mot algate and nedes wile / Noght only make my spekynges / Of love, bot of othre thinges, / That touchen to the cause of vice" (I.238-41; and cf. I.267-9). As a result, there is often a marked disjunction between Amans' account of his unsuccessful love affair and Genius's exposition of the seven deadly sins. While Genius's discourse moves gradually if unevenly towards the instruction on ethics and self-government found in Book VII and (more implicitly) in Book VIII, Amans' own story fails to make any clear progress. His desire for guidance about how to achieve his love is frustrated and in the conclusion he is instead forced to abandon his pursuit. While he is made to admit his own inadequacies as a ridiculous senex amans and to give up his "unwise fantasie" (VIII.2866), Gower's impotent and increasingly isolated poetic persona continues to fall far short of Genius's ideal of the chaste and rational married man outlined in VII.4215-4237. Indeed if it is at times tempting--although anachronistic-to think of the relationship between Genius and Amans not only as that of priest and penitent, but also as that of psychoanalyst and patient, ${ }^{23}$ it is evident that the two often appear to be speaking at cross purposes. Sometimes--most notably in Book VII where

\footnotetext{
23 Braswell draws this comparison in Medieval Sinner, 82. In his History of Sexuality, Foucault argued that confession and psychoanalysis were part of the same tradition: see also "The Confession of the Flesh" in Power/Knowledge: Selected Interviews and Other Writings 1972-1977, ed. Colin Gordon, transl. Colin Gordon, Leo Marshall, John Mepham, and Kate Soper (Brighton: Harvester, 1980), 194-
} $228 ; 209-222$. 
Genius directs his attention to the conduct of princes--it is not even clear that he is talking to Amans at all, except in so far as the monarch is intended to be read as a representative or everyman figure. Perhaps then, it should come as no surprise that the "talking cure" seems to fail in this instance. As I will explain toward the end of this article, it is in the context of this communication failure between Genius and Amans that Genius's silence on the subject of male sodomy can begin to be understood. First, however, I will look at some of the occasions in which Genius discusses other forms of effeminate and immature behavior and transgressive desire.

\section{Hercules}

In the course of the eight books of Confessio Amantis, the priest Genius relates to the penitent Amans three stories about transvestitism, transgendering and transsexuality: the tales of Deianira and Nessus (II.2145-2307), Achilles and Deidamia (V.29613201), and Iphis (IV.451-505). Genius intends each of these narratives to exemplify a different vice or virtue. In none of them is the act of cross-dressing immediately relevant to the sin in question, nor for that matter, to the lover's own transgressions. The story of Deianira and Nessus in Book II, for example, is narrated by Genius as a warning to Amans against the sin of "Falssemblant", or False Appearance.

"Falssemblant" is a vice associated with masquerade and artful words; it is aligned with hypocrisy, and like hypocrisy, it is a form of envy. Ostensibly, it is the giant Nessus who is guilty of this vice in his deception of Hercules and Deianira: he offers to carry both across a deep river, but abandons the former, and attempts to abduct the latter. But the story doesn't end here. Hercules both survives the river and shoots his foe with a poisoned arrow. Yet even as he is dying, Nessus continues to behave deceptively. He gives Deianira his bloody shirt, falsely promising that it will rekindle Hercules' love, should it ever fail. 
The cross-dressing occurs in the continuation of the story, and it has the effect of undermining the moral. Suddenly Hector is no longer an innocent victim. He abandons Deianira for another woman, Eolen, and his new love makes him so "nyce" [foolish, delicate] (II.2268) and "assote" [besotted] (II.2269) that the adulterous couple take to dressing up in each other's clothing (II.2270-1). ${ }^{24}$ At this point Deianira remembers Nessus's gift of the shirt and contrives to make Hercules wear it. However, this shirt, which metaphorically causes Deianira to burn with joy, ("Hire thoghte hire herte was afyre": II.2256) is a pyrogen. Hercules' subsequent suffering drives him to such a state of madness that he destroys himself in a self-made fire. From this, it seems that Hercules' death is less the consequence of Nessus's deception, and more the punishment for his own subsequent foolishness. Hercules' act of cross-dressing is itself a form of "Falssemblant." The image of Hercules wearing a woman's coat is symbolic of his self-emasculation and loss of identity; as the narrator states: "thus fieblesce [weakness] is set alofte, / And strengthe was put under fote" (II.2272-3).

This first cross-dressing narrative clearly illustrates the connection between cross-dressing and effeminacy. Effeminacy is condemned outright by Gower on a number of occasions. In Vox Clamantis, for example, the reader is warned that "Demon femineos et molles diligit actus, / Quando viri virtus omne virile negat"

\footnotetext{
${ }^{24}$ This episode of the tale does not occur in Ovid's Metamorphoses (Gower's main source for the tale),

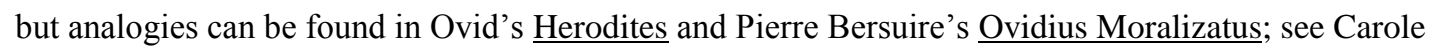
Koepke Brown, "The Tale of Deianira and Nessus" in John Gower's Literary Transformations in the Confessio Amantis, ed. Peter G. Beidler (Washington D.C.: University Press of America, 1982), 15-19; 18; and Conrad Mainzer, “John Gower's Use of the 'Mediaeval Ovid' in Confessio Amantis”, Medium Evum 41 (1972), 215-19; 217.
} 
[Whenever a man's virtue will have no part in anything virile, the Devil highly favors his weak, womanly behavior] (III.xxvi.1977-8). ${ }^{25}$ In Book VII of Confessio, Genius asserts that "It sit a man be weie of kinde" [it is natural for a man] to love, but it is "it is noght kinde" [it is unnatural] for a man to lose his wits for love (VII.4297-9), and that such effeminate folly, which renders the strong feeble, is like frost in July, heat in December, or, significantly, in a sartorial context, the hose worn over the shoe (VII.4300-4307). The first of the "olde ensamples" Genius cites to illustrate the error of those who "for love hemself mislede, / Wherof manhode stod behinde" (VII.431012 ) is that of King Sardanapalus. Sardanapalus was so overcome by the fiery rage of love that he became "womannyssh" quite against "kinde" or nature, like a fish living on the land (VII.4231-3). ${ }^{26}$ Shutting himself in his chamber in the company of women, he learnt how "a Las [lace] to breide [braid], / And weve a Pours, and to enfile [thread] / A Perle." (VII.4332-4) When his enemy Barbarus discovered "hou this king in wommanhede / Was falle fro chivalerie" (VII. 4336-7), he took his chance to invade his kingdom. ${ }^{27}$ The moral of this exemplum, which occurs within a larger discussion about the importance of chastity, is unquestionably that luxuria [lust, or, in a broader senses, inordinate desire and intemperance] threatens masculinity. As is

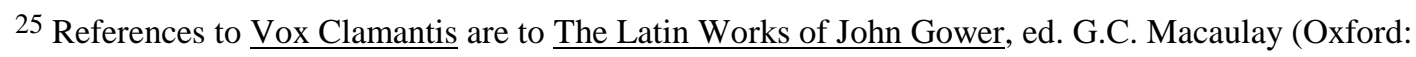
Clarendon Press, 1902); translations are taken from The Major Latin Works of John Gower, transl. Eric W. Stockton (Seattle: University of Washington Press, 1962).

26 "Wommanysshe" is glossed by Macaulay as "womanly" or "effeminate."

${ }^{27}$ Other examples of such folly include the Lydians (VII. 4361-4405) and the Hebrews (VII.44064445). The folly of the Hebrews is also described in Vox Clamantis VI.xii.871-902, in the context of an admonition to the King to marry and to avoid the allurement of sins of the flesh.
} 
appropriate enough with the advice to princes' section of Confessio, Genius, as Gower's mouthpiece, directs his warning to the monarch:

Therfore a Prince him scholde avise,

Er that he felle in such riote,

And namely that he nassote

To change for the wommanhede

The worthinesse of his manhede.

(VII.4252-56)

Genius avers that the only solution is for a man to "love streite"(VII.4280) and then he will not be bound by women. "Streite" love in this context appears to mean moderate love.

Like immoderate desire--or love which is not "streite"-- male cross-dressing is thus viewed in Confessio as a travesty of masculinity, and thus like all forms of effeminacy it is a symptom of ethical misgovernance. The conclusion of the tale of Nessus and Deianira reveals that identity is known or constructed as much through knowing what one is not, as through knowing what one is. Hercules--renowned for his physical prowess and courage--has undermined his greatness, his very selfhood, by donning the apparel of a weak woman. Seeming to be what he is not brings about an ontological crisis, which can only be resolved by self-destruction. ${ }^{28}$

\footnotetext{
${ }^{28}$ Gower's portrayal of Hercules's divided nature is traditional. From the Classical period onward, Hercules was renowned known not only for his great strength but also for his intemperance and lascivious nature: see G. Karl Galinsky, The Herakles Theme: The Adaptations of the Hero in

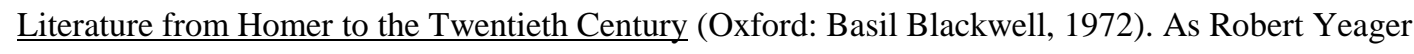
puts it, Hercules reputation is "piebald": John Gower's Poetic: The Search for A New Arion (Cambridge: D.S. Brewer, 1990), 89.
} 


\section{Achilles}

The story of Hercules raises questions about gendered identity, which are explored elsewhere in Confessio Amantis. In Book V, in the tale of Achilles and Deidamia, notions of masculinity are interrogated further. Once again there is a disjunction between the topic of discussion and the exemplary narrative. This exemplum is intended to illustrate the evils of "Falswitnesse," a form of covetousness. "Falswitnesse" is a vice not dissimilar to "Falssemblant" in that it too profits from lying and treachery: it is another form of verbal masquerade. In this case it is Thetis, Goddess of the Sea, who (indirectly) deceives another woman, Deidamia, daughter of king Lichomede. Thetis, in an attempt to prevent him going to Troy, disguises her son Achilles as a maiden and sends him to Lichomede's household, where he becomes Deidamia's bedfellow and then lover. According to Genius's earlier definition, "Falswitnesse" in love is a form of secret procuration--not only in the sense of inducing or urging, but also in the sense of pimping (V.2903-13). ${ }^{29}$ Thus, Thetis is, by implication, further guilty of "Falswitnesse" in so far as she effectively procures Deidamia for her son by bringing it about that he sleeps in her bed.

And one might argue that just as Hercules is guilty of "Falssemblant" in dressing up in his lover's clothes, so Achilles is guilty of "Falswitnesse" in pretending to be a maid. Although not aware of his mother's motives, Achilles "buxomly" [obediently, submissively, willingly] colludes with her plan (V.3030), smiling to himself at the success of his disguise (V.3012-13), or even, as Rosemary Woolf

\footnotetext{
${ }^{29}$ By the seventeenth century to "procure" could mean "to obtain (women) for the gratification of lust" (OED 5b), and a "procurer" could have the sense of "one who procures women for the gratification of lust; a pander" (OED 4). The MED does not offer comparable definitions, but Gower's use of the word "procurours" suggests that in the late Middle Ages it had similar connotations.
} 
suggests, relishing "a moment of sexual indeterminacy."30 As Woolf observes, at this point Gower adapts his source (Statius's Achilleid) in which Achilles is disgusted at having to dress as a woman and does so only with reluctance. However it should be noted that Gower may be influenced here by a version of the story found in Alain de Lille's Anticlaudianus, in which Achilles is censured as degenerate because he deliberately took upon himself the role of a woman. ${ }^{31}$ At any rate, in Gower's version, Achilles reveals his duplicitous nature once and for all when he abandons his lover to join the Greek army.

Interestingly, the third figure in this story who might be accused of "Falswitnesse" alongside Thetis and Achilles is Ulysses, who is sent with Agamemnon to seek out the hidden boy. Here eloquence reveals itself as a form of "Falswitnesse," when Ulysses, "which hath facounde" (V.3126) greets Lichomede, but disguises his true intent, choosing to discover the young hero's identity by trickery rather than exhortation. Here the link between gender transgression and ethical misgovernance is once more reinforced, if somewhat indirectly, since it is only elsewhere in $\underline{\text { Confessio, }}$, that the smooth-talking Ulysses is revealed to be guilty of effeminacy. In Book IV, Ulysses is accused by Nauplus of dishonoring his reputation by feigning madness and staying at home with his wife rather than fighting like a man: "'that thou for Slouthe of eny love / Schalt so thi lustes sette above / And leve of armes the knyhthode, / Which is the pris of thi manhode / And oghte ferst to be desired"” (IV.1877-81). Genius then contrasts Ulysses with Protesilaus, who

\footnotetext{
30 Woolf, "Moral Chaucer and Kindly Gower," 224. See also Lochrie, Covert Operations, 216-217.

${ }^{31}$ Alain de Lille, Anticlaudianus, ed. R. Bossuat (Paris: Librairie de Philosophique J. Vrin, 1955), 9.265-269; Alan of Lille, Anticlaudianus, transl. James J Sheridan (Toronto: Pontifical Institute of Mediaeval Studies, 1973), 211.
} 
exemplified manly prowess, refusing to pay attention to the "wommannysshe drede" (IV.1924) of his spouse and embracing the prospect of losing his life in battle.

However, while still associated with effeminacy, Achilles' cross-dressing is also linked to immaturity. Whereas Hercules' death is vividly, if briefly, described, the story of Achilles breaks off at the point of his departure for the Siege of Troy. Unlike Hercules, Achilles is not punished for dressing as a woman. His sin of "Falswitnesse" is apparently forgiven. One likely explanation for this seeming discrepancy is that Achilles is not held culpable because his cross-dressing is engineered by his mother and because he indulges in it when he is not yet fully a man. Indeed, the narrator emphasizes that his appearance and manner are actually those of a child (V.3014-21) ${ }^{32}$ Consequently, Achilles' masculinity, unlike that of Hercules, is never really in question. His feminine appearance ["wommannysshe chiere"] is something which he quite consciously puts on, and his manliness is something which has to be restrained (V.3050-55). The subsequent adoption of his masculine identity is represented as maturation. This does not occur, as we might expect, when he sleeps with a woman, even though this is described in terms of Nature and "kinde" [natural law] asserting themselves (V.3058-69). Rather, Achilles only fully assumes a traditional male identity when he is made to choose between women's dress and the trappings of chivalry (V.3152-67). In an episode derived from Statius (Achilleid) and Ovid (Ars Amatoria),${ }^{33}$ but perhaps also reminiscent of the romance of Perceval, ${ }^{34}$

\footnotetext{
${ }^{32}$ For another, briefer, analysis of Achilles' effeminacy, see Ad Putter, “Arthurian Literature and the Rhetoric of Effeminacy" in Arthurian Romance and Gender: Selected Proceedings of the XVIIth International Arthurian Congress, ed. Friedrich Wolfzettel (Amsterdam: Rodolphi, 1995), 34-49; 42. 33 See Katherine Callen King, Achilles: Paradigms of the War Hero from Homer to the Middle Ages (Berkeley: University of California Press, 1987), esp. 180-184.
} 
Achilles is entranced by the shining gear and hastens to arm himself (V.3168-85).

Achilles' female disguise signifies his childhood when he remains under the influence of his mother. His arming is a rite of passage. He forgets his promise to his mother, and joins Ulysses and Diomedes. It is significant that it is at this stage in the narrative (and not earlier) that we are told that Deidamia is going to have his child (V.3194-5).

\section{Iphis}

So far, these stories have focused on the effect of transvestitism and transgendering on men. In the story of Hercules, the narrator did not comment on Eolen's crossdressing: there was no suggestion that she was punished for putting on a man's clothing. This might indicate that women's cross-dressing has a different meaning to men's, a theory that is strengthened by Gower's tale of Iphis and Ianthe. This narrative bears some resemblance to that of Achilles. Once again the mother plays a central role: on the instructions of the goddess Isis, Iphis's mother brings up her daughter as a boy, in this case, to save her from her father, who vowed that he would have the infant slain at birth if it were a girl. At the age of ten the child Iphis is wedded to a Duke's daughter, Ianthe, and eventually the two girls become lovers, a union memorably described by Christopher Ricks as "“sche and sche': it is magnificent, but it is not marriage." 35

\footnotetext{
34 See for example Chrétien de Troyes, "Perceval: the Story of the Grail," Arthurian Romances, transl. D.D.R. Owen (London: Everyman, 1993), 374-495; 375-8. For a reading of the Middle English $\underline{\text { Sir }}$ Perceval of Galles which argues that Perceval moves from the maternal sphere into the paternal and then back into the maternal, see F. Xavier Baron, "Mother and Son in $\underline{\text { Sir Perceval of Galles," }}$ Papers in Language and Literature 8 (1972), 3-14.

35 Christopher Ricks, "Metamorphosis in Other Words" in Gower's Confessio Amantis: Responses and

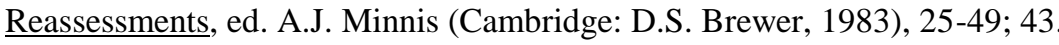


The narrative of Iphis is far from straightforward and has resulted in some critical confusion. Whereas Rosemary Woolf defines the relationship between Iphis and Ianthe as homosexual, Patrick J. Gallacher claims that "nature prohibits physical expression of their love."36 Gallacher's reading of the narrative seems unlikely given that Gower adapts his source (Ovid's Metamorphoses) so that both the marriage has taken place and the sexual relationship has developed before the conflict surrounding Iphis's sex has been resolved. However a clue to Gallacher's reading lies in the Latin commentary. In the marginal gloss at IV.455 we are informed: "Set cum Yphis debitum sue coinage vnde soluere non habuit, deos in sui adiutorium interpellabat" [But when Iphis did not have it in her power to honor the debt owed to her spouse, she prayed to the gods in their oratories]. This commentary is at odds with the English text, which does not mention Iphis's prayer, and which seems to suggest that Iphis does have it in her power to honor her marriage debt. We are told that Iphis and Ianthe, lying side by side in bed, find themselves compelled not only by proximity, but also by Nature (possibly meaning simply "sexual instinct" in this case) "so that thei use [practice] / Thing which to hem was al unknowe [a thing unknown or alien to them]" (IV.486-7).

The discrepancy between the Latin and English verses is symptomatic of the confusion that lies at the heart of Gower's telling of this story. Woolf argues that "Gower has obscured the moral issue ... by some unclear generalizations." 37 Whereas

\footnotetext{
36 Woolf, "Moral Chaucer, Kindly Gower,” 225; Patrick J.Gallacher, Love, the Word, and Mercury: A

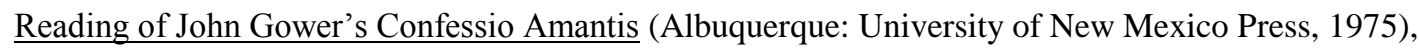
67. See also Lochrie, Covert Operations, 213-216, and Carolyn Dinshaw, Getting Medieval:
}

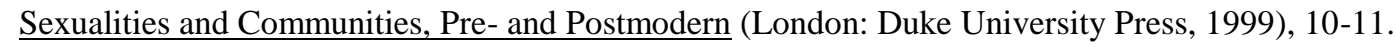
37 “Moral Chaucer, Kindly Gower," 225. 
in Ovid, Iphis laments that her desire for another woman is monstrous and unnatural, in Gower's Middle-English version, she makes no such complaint, implying perhaps that neither she nor Genius views it as such. Nonetheless, in the next few lines, Cupid's intervention ${ }^{38}$--his decision to transform Iphis into a man--is described in terms of reasserting the supremacy of "kinde" and "kinde love" (IV.488-505). In other words, although driven by nature ("Nature ... Constreigneth hem”: IV.484-6), the love shared by Iphis and Ianthe is, paradoxically, now defined as an offense against natural law: "For love hateth nothing more / Than thing which stant ayein the lore / Of that nature in kinde hath sett" (IV.493-5). ${ }^{39}$ The resolution of the tale is indeed, as Genius asserts, a "wonder" in the sense of "a marvel" or "a miracle", but possibly also in the sense of an "evil" or a "disaster" (IV.445). ${ }^{40}$

Genius's confusion reflects medieval attitudes to sex between women. Even though such sex came under the definition of sodomy, it seems to have been more or less invisible in Gower's own society: there is little or no surviving evidence in England or Wales of women being examined about sexual misconduct with women. ${ }^{41}$

\footnotetext{
38 In Ovid it is Isis, the goddess of good hope, who intervenes. Cupid's intervention here points outward to the frame narrative in which Cupid's interventions both cause Amans's obsession and release him from it.

${ }^{39}$ For an attempt to resolve the confusion surrounding Nature and "kinde" in the Tale of Iphis and Ianthe, see R. F. Yeager, "Learning to Read in Tongues: Writing Poetry for a Trilingual Culture" in Chaucer and Gower: Difference, Mutuality, Exchange, ed. R. F. Yeager, ELS monograph series no.51
} (Victoria B.C.: University of Victoria Press, 1991), 115-29; 120-6. For more recent responses, see Lochrie, Covert Operations, 214-215, and Dinshaw, Getting Medieval, 10-11.

40 OED 1a, 2a, 5a, and 5b.

${ }^{41}$ For an overview of surviving evidence in Europe, see Jacqueline Murray, "Twice Marginal and Twice Invisible: Lesbians in the Middle Ages" in Handbook of Medieval Sexuality, ed. Vern L. 
Despite his later assertion that the "madle" [male] is made for the "femele" [female] (VII.4215), Genius seems unwilling to condemn Iphis. The age of her betrothal (thirteen in Ovid) is changed to ten, and although it is suggested that time passes before the two women have sex (IV.481: "withinne time of yeeres"), Iphis would not have been considered old enough to bear criminal responsibility. ${ }^{42}$ Furthermore, her innocence, or rather ignorance, is explicitly commented upon. As with the story of Achilles, childhood seems to be a space of legitimate transgression. Nonetheless, within a Christian moral framework neither Achilles nor Iphis would be entirely exonerated from blame, because from the age of seven (the age of reason) children were believed to be able to distinguish good from evil. ${ }^{43}$ But if Gower is ambivalent about lesbian sex, he does not represent as problematic Iphis's transformation into a man (it is, in fact, anticipated by his, albeit inconsistent, use of masculine pronouns from the start of the story). One explanation for this is that according to certain theories of medicine, the one sex model, the transformation from female to male was

Bullough and James A. Brundage (New York: Garland, 1996), 191-222; most of the examples cited are from continental Europe.

${ }^{42}$ Twelve seems to have been the crucial age for girls (fourteen for boys), see Shulamith Shahar, Childhood in the Middle Ages, trans. Chaya Galai (London: Routledge, 1992), 24-6. If found guilty of a sexual sin, a child under the age of legal responsibility would usually be treated more leniently than an adult would.

${ }^{43}$ See Shahar, Childhood, 23-26, 77-120 and 162-182. Gower does not specify Achilles' age when he is cross-dressing, but despite his childish appearance he is evidently not in his infancy because (all other factors, including sexual maturity, apart), in the Middle Ages, girls and boys would generally have been dressed the same in the first age of childhood. For a further important example of childhood as a space for legitimate transgression (in this case, incest), see the story of Canace (III.143-336). 
not in itself contrary to nature. ${ }^{44}$ Indeed because women were perceived to be inferior to men, such a transformation could only be seen as an improvement, a change from an imperfect state to a perfect one; it could bestow on the woman a potency she would otherwise lack. It must be said that Iphis does not undergo any sort of identity crisis. Whereas male cross-dressing poses a problem for Genius because by implicating the heroes, Hercules and Achilles, in the sins of Nessus and Thetis, the morals of the exemplary narratives become confused as the boundary between ethical and unethical behavior is crossed, the same is not true of female cross-dressing. Unlike Hercules, Iphis suffers no punishment for cross-dressing (quite the opposite, as she is rewarded for her perseverance as for a virtue), and unlike Achilles, she does not grow out of it. In fact, Iphis appears as one of the few desiring female subjects and exemplary female lovers in the text; exemplary, perhaps, because she exhibits virtues constructed as masculine rather than feminine. In her story, unlike those of Hercules or Achilles, cross-dressing is not intended to exemplify the evils of deception. Rather, the tale illustrates the vice of Pusillanimity or Faint Heartedness, that lack of determination that is a form of Sloth. According to Genius, pusillanimity detracts from masculinity: the lover guilty of this vice "woll no manhed understonde, / For evere he hath drede upon honde" (IV.325-6). Later in the same Book, Genius encourages Amans with the words "Mi Sone, it is wel resonable, / In place which is honorable / If that a man his herte sette, / That thanne he for no Slowthe lette / To do what longeth to manhede" (IV.2029-2033). Iphis is apparently cited as the opposite

\footnotetext{
44 See Thomas Laqueur, Making Sex: Body and Gender from the Greeks to Freud (London: Harvard University Press, 1990), esp. 134-142; but also Joan Cadden, The Meanings of Sex Difference in the Middle Ages: Medicine, Science, and Culture (Cambridge: Cambridge University Press, 1993), esp. 3.
} 
of pusillanimity, as a positive example of the strength of character necessary to win love:
And thus to take an evidence,
It semeth love is welwillende
To hem that ben continuende
With besy herte to poursuie
Thing which that is to love due.

(IV.506-10)

Iphis can be usefully compared to the Amazon queen Penthesilea, who, inspired by the twinned chivalric ideals of love and honor in war, came to the rescue of Hercules in the siege of Troy (IV.2141-2). ${ }^{45}$ While Penthesilea's attire is not specifically mentioned, it can be assumed that she dons armor before entering battle. ${ }^{46}$ Penthesilea's significance should not be underestimated. She is mentioned three times in all: here as an example of Prowess (IV.2135-82), and again as an example of wealth (V.2547-51), and as a member of the Company of Youthful Lovers (VIII.2525-7). Penthesilea, then, can be cited as another example of a cross-dressing

\footnotetext{
45 Another example of a desiring female subject is the daughter of the king of Pentapolis, who sends a secret letter to her father telling him that she has resolved to marry Apollonius of Tyre (VIII.894-90). However her anonymity reveals the extent to which she functions simply as an object to be exchanged between men (her father and husband), and is thus marginalized within the narrative as a whole. For a recent analysis of Gower's Tale of Appollonius of Tyre, which is sensitive to the representation of women, see Larry Scanlon, "The Riddle of Incest: John Gower and the Problem of Medieval Sexuality"

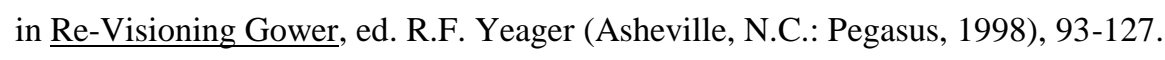

46 See William Blake Tyrrell, Amazons: A Study in Athenian Mythmaking (Baltimore: John Hopkins University Press, 1984), 49-52.
} 
heroine who is intended as a positive role model for Amans, and as another woman who exemplifies masculine virtue. ${ }^{47}$

\section{The Lack of Sodomy}

In my analysis so far I have concentrated largely on issues of gender difference (specifically effeminacy and female masculinity), and the question of homosexuality or sodomy has been addressed only in relation to the tale of Iphis. However, as I have already indicated, Gower's infamous preoccupation with incest suggests the centrality of sexuality--especially subversive sexuality--to the text as a whole. It is a significant point, then, that out of all of these cross-dressing narratives, which in their different ways explore the interconnection of transgressive gender and subversive sexuality, only one discusses a same-sex sexual relationship. And it is equally significant that the tale of Iphis and Ianthe is one of only two of the eight stories about same-sex desire which are sympathetically recounted in the Metamorphoses to be retold by Gower. ${ }^{48}$ The other is the tale of Narcissus (I.2275-2366).

Gower's treatment of this narrative draws our attention to what he is omitting. In Ovid's Metamorphosis, the proud and beautiful Narcissus, at the age of sixteen, is between boy and manhood. He is extremely attractive to both boys and girls, but only the nymph Echo dares approach him. After his rejection of Echo, he is punished for his selfish chastity by Nemesis who causes him to fall in love with his own reflection.

\footnotetext{
${ }^{47}$ Lochrie views Gower's Iphis more negatively, arguing that by cross-dressing she becomes a caricature of a prince, and "of the masculinity it implies": Covert Operations, 216.

48 The complete list, as provided by Mark Jordan, The Invention of Sodomy in Christian Theology (Chicago: University of Chicago Press, 1997, 81 n.70 is: Narcissus, Athis and Lycabas, Cycnus and Phyllius, Iphis and Ianthe, Orpheus, Cyparissus and Apollo, Ganymede and Jupiter, and Hyacinth and Apollo.
} 
As he comes to the realization that the boy whom he desires is his own image, he is consumed by an inner fire. Mark Jordan has argued that Alain de Lille adapted the story as an implicit condemnation of irregular sex, "to illustrate the danger of selflove, that is, the danger of the love of a body for another of the same kind." 49 From Genius's conclusion it might seem that Gower's English version has a similar moral: the flower that springs up on Narcissus's sepulcher and grows in winter "is contraire / To kynde, and so was the folie / Which fell of his Surquiderie" (I.2356-8). Yet Gower's reshaping of the narrative removes the possibility of interpreting Narcissus's love as homosexual. We are told,

He sih the like of his visage,

And wende ther were an ymage

Of such a Nimphe as tho was faie,

Wherof that love his herte assaie

Began, as it was after sene,

Of his sotie and made him wene

It were a womman that he syh.

The Latin gloss goes further still, and identifies the image with Echo: "ipse faciem suam pulcherrimam in aqua percipiens, putabat se per hoc illam Nimpham, quam Poete Ekko vocant, in flumine coram suis oculis pocius conspexisse" [seeing his own very beautiful face in the water, he thought himself to be in the presence of that Nymph whom the poets call Echo, rather than gazing into his own eyes] (at I.2279).50

\footnotetext{
49 Jordan, Invention of Sodomy, 83.

50 Translated by Siân Echard, "With Carmen's Help: Latin Authorities in the Confessio Amantis," Studies in Philology 95 (1998), 1-40; 36.
} 
Siân Echard suggests that this explanatory allusion to Echo "could be seen as an attempt to efface possible homoerotic implications in the original version of the tale." $" 51$

This is certainly not the only instance when Gower, or Genius, avoids the homosexual or homoerotic possibilities of his sources. For example, Genius does not make any allusion to Hercules' love for the youth Hylas, ${ }^{52}$ or to Achilles' reputation as the friend and possibly lover of Patroclus (surely known to him through his reading of Benoît de Sainte-Maure, or perhaps even Alain de Lille). ${ }^{53}$ Indeed the nearest Genius comes to discussing the sin of sodomy is in the tale of Hercules and Faunus in Book V (6807-6935). Here Genius returns to the affair between Hercules and Eolen and on this occasion the exchange of clothing is described in almost loving detail with the former being represented as submitting to his woman's playful whims: Eolen dresses in her lover's lion skin, ties his mace to her belt and winds a wimple around his face. In this instance, cross-dressing serves to protect the woman (although not the man) from sexual assault when the lustful Faunus mistakenly climbs on top of a

\footnotetext{
51 Echard, "With Carmen's Help," 37. Echard's main point is, however, that at the same time Gower is "drawing attention to the unreliability of both the English and the Latin parts of the text" [Echard's emphasis]. Again my reading of this episode can be compared to that by Lochrie, Covert Operations, 219-221

52 See Galinsky, Herakles Theme, 109-122.

53 Jordan claims that the "literate reader" would automatically think of Achilles in terms of his relationship with Patroclus: Invention of Sodomy, 73-4; but see also King, Achilles, 171-172. For the passage in Alain de Lille which seems to refer to Achilles' homosexuality, see "De Planctu Naturae," ed. Nikolaus M. Häring, Studi medievali, series 3, 19 (1978), 797-879: metrum 1 lines 55-6; Alan of Lille, The Plaint of Nature, transl. James J. Sheridan (Toronto: Pontifical Institute of Medieval
} Studies, 1980), 72. 
sleeping Hercules. However the homoerotic potential of this confusion is undeveloped, or at any rate displaced into virile physical aggression: Hercules wrestles Faunus to the floor and leaves him lying there humiliated. ${ }^{54}$ This episode might be dismissed as a humorous interlude, but it gains significance from resonances elsewhere in the text. Faunus was often identified with the lover's antagonist Pan, ${ }^{55}$ and, as we have already seen, Amans considers himself doomed to fight a losing battle against love in an eternal wrestling match.

I suggested earlier that Genius's evasion of the subject of male sodomy relates in some way to the communication failure between Genius and Amans. It is not simply that Genius is an inept confessor, whose choice of exempla sometimes appears bizarre, whose meaning is often unclear, and who frequently loses sight of the circumstances of his penitent (an obvious example being Genius's discussion of incest, which is manifestly irrelevant to Amans' own situation, as the lover himself points out at VIII.2034-9). ${ }^{56}$ The silence about male sodomy relates to a larger problem within penitential literature more generally: how to be specific about sexual sins, without leading either the confessor or the penitent into a sin which they might not otherwise have imagined, or into a (sexual) relationship which would not

\footnotetext{
${ }^{54}$ Lochrie does not see any homoeroticism in this passage, but observes that the narrative functions to trivialize rape and thus overlooks the violation of women inherent in the medieval ideology of romantic love: Covert Operations, 218-219.

55 Merivale, $\underline{\operatorname{Pan}}, 8-9$.

56 I take a much more negative view of Genius's failings as a confessor than Kinneavy does in “Gower's Confessio Amantis."
} 
otherwise have developed. 57 Near the start of Book I, Genius outlines to Amans his confessional procedure:

Of my Presthode after the forme

I wol thi schrifte so enforme,

That ate leste thou schalt hiere

The vices, and to thi matiere

Of love I schal hem so remene,

That thou schalt knowe what thei mene.

For what a man schal axe or sein

Touchende of schrifte, it mot be plein,

It nedeth noght to make it quiente,

For trowthe hise wordes wol noght peinte:

That I wole axe of the forthi,

My Sone, it schal be so pleinly,

That thou schalt knowe and understonde

The pointz of schrifte how that thei stonde.

In confession, plain style, Genius asserts, is the order of the day, and indirect or figurative language is to be avoided. But, as his own use of exemplary narratives illustrates, such an ideal cannot always be sustained; didacticism has to be clothed as entertainment, "lore" has to be dressed up in the language of "love." In many instances, the indirect approach proves to be the most acceptable, if not the most effective. As I have already suggested, sodomy is one such instance. Chaucer's

\footnotetext{
${ }^{57}$ Pierre J. Payer, "Sex and Confession in the Thirteenth Century" in $\underline{\text { Sex in the Middle Ages: A Book }}$
} 
Parson referred to it as "thilke abhomynable synne, of which that no man unnethe oghte speke ne write." 58 Similarly, John Mirk instructed priests that they should not raise the issue of the "synne a3eynes kynde" but only warn penitents indirectly that to "do hys kynde other way, / Pat ys gret synne wypowte nay." 59 When it came to sodomy--and sodomy committed by men in particular--priests could only "grope" in the dark, in the Middle-English sense of hearing confession or examining someone's conscience. ${ }^{60}$ As a consequence, there was always the possibility that their warnings would go unheard, that their words would be misunderstood. This is what seems to happen in Confessio. Genius avoids the subject of sodomy in relation to the practices of men because it might prove too close to the bone. However, because this poem, like so many other confessional texts, is limited by its masculine perspective, the same difficulties do not apply to the sodomitical practices of women. But because Genius does ignore the subject of male sodomy, Amans has, quite simply, no idea that it might be an issue.

In conclusion then, Genius's position on gender transgression and subversive sexuality is ambivalent: while "honeste love" (marriage) and self-governance are praised, transvestitism, transgendering and transsexuality are explored and even, at times, allowed to undermines norms of gender and sexuality. They are treated differently according to context, and according to the ethical issues raised. Hercules is viewed as effeminate because he is besotted with a woman, and because in dressing as

of Essays, ed. Joyce E. Salisbury (New York: Garland, 1991), 126-41; 127.

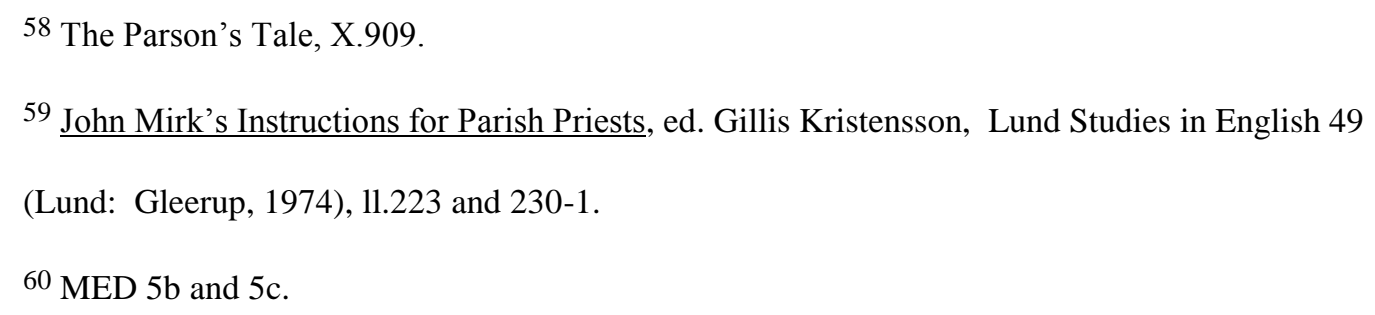


a woman, he is guilty of "Falssemblant". He can thus be compared to negative exemplary figures like Sardanapalus, or even Ulysses. Achilles' cross-dressing is legitimized by his youth and because his chivalric masculine identity asserts itself. It is not a form of "Falswitnesse" in so far as he remains true to himself. Iphis, like Penthesilea, is taken as a positive "masculine" role model. These narratives destabilize not only male/female boundaries but also the oppositions of manliness and effeminacy, the ethical and the unethical, and the natural and the unnatural. Confessio presents the reader with a series of paradoxes. Nature can inspire unnatural desires and actions. It is possible, even desirable for a woman to behave like, or to turn into a man. The most manly of heroes can become effeminate. The most exemplary of figures can behave immorally, and vice versa. Yet, while neither female crossdressing nor female homosexuality is condemned out of hand, male sodomy remains taboo. Although not divorced from other types of failure of self-governance or from other forms of excessive desire, male homosexuality is a topic which is silenced within confessional discourse, and which can endanger the relationship between priest and penitent. From the very beginning of the poem, doubts have been raised as to Amans' sincerity (see, for example, Venus's observation at I.173-6). Although Genius probes deeply, if not very effectually, and continually stresses the importance of not deceiving oneself (e.g. VIII.2140-1), one question remains. Is it simply Amans' folly as a senex amans, or a more deeply hidden sin, which ultimately constitutes the "unwise fantasie" of which he must rid himself? 